DOI: https://doi.org/10.24144/2409-6857.2018.2(52).57-62

УДК 330.34.014-026.23:338.22:005.52:005.334(203)

Колодійчук А.В.

\title{
ВЕРХНЬОАТМОСФЕРНІ РИЗИКИ ВПРОВАДЖЕННЯ ІКТ: ЕКОЛОГО-ЕКОНОМІЧНИЙ ЗМІСТ ТА КЛАСИФІКАЦІЯ
}

\begin{abstract}
У статті охарактеризовано верхньоатмосферні екологічні ризики впровадження інформаційнокомунікаційних технологій, наведено їх класифікацію. Зокрема, розглянуто ракетні, корабельні, супутникові та орбітальні класи ризиків практичного застосування сучасних IКТ-систем. В розрізі даних класів загроз мова йде про такі конкретні ризики, як: ризики механічного забруднення територій $i$ ураження людей обломками космічного сміття; ризики хімічного зараження; ризики зіткнень апаратів у ближньому космосі; ризики забруднення навколишнього космічного простору; терморизики для апаратної складової $і$ екіпажів; радіаційні ризики; екоризики фізичних властивостей атмосфери. Виявлені негативні еколого-економічні наслідки прояву цุих ризиків.
\end{abstract}

Ключові слова: атмосфера, геофізичні ракети, інформаційні і комунікаційні технологї (IКT), ризики, радіація, екологічні проблеми, космічне сміття, економічні збитки.

Постановка проблеми. У повсякденному житті ми дуже часто спостерігаємо пропагування широкого i всестороннього впровадження у національно-господарський виробничий комплекс нових технологічних досягнень у сфері інформаційно-комунікаційних технологій. Проте, при цьому майже не говориться про шкідливий вплив таких технологій на природні екосистеми, серйозне порушення екологічного балансу територій, протікання природних процесів, хімічне забруднення повітря та навколишнього середовища. Комп'ютерним корпораціям та виробникам цифрового обладнання не вигідно збільшувати собівартість своїх продуктів за рахунок збільшення рівня їх екобезпечності; вони обмежуються дотриманням поверхових екологічних норм, встановлених законодавствами тих країн, на ринках яких вони працюють. Не $є$ винятком і великі науково-виробничі центри, які створюють штучні супутники Землі, ракети, космічні апарати, та всі інші об'єкти космічної промисловості, прямо або опосередковано задіяні у цьому процесі.

Аналіз останніх досліджень i публікацій. Питанням розвитку космічної промисловості, іiі ресурсозабезпеченню, забезпечення галузевої конкурентоспроможності та управлінським аспектам приділена увага багатьох науковців, серед яких: Ю. Алексєєв, В. Буторіна, Є. Срмоленко, М. Лукашов, О. Палагін, С. Паршин, Д. Черникова та ін. В той же час атмосферним екологічним ІКТ-ризикам приділено занадто мало уваги, в економічному плані

(c) Колодійчук Анатолій Володимирович, к.е.н., доцент кафедри фінансів «Ужгородський торговельноекономічний інститут Київського національного торговельно-економічного університету, м. Ужгород вони систематизовано на науковому рівні не розглядалися, а тому ми спробуємо цю прогалину заповнити.

Формулювання цілей статті. Мета статті побудувати класифікацію верхньоатмосферних екологічних ризиків впровадження IКT та виявити їхні негативні еколого-економічні наслідки для національних економік та стану довкілля.

Опис основного матеріалу дослідження. До групи атмосферно-космічних ризиків функціонування IКТ-них систем ми віднесли такі підгрупи потенціальних загроз, як: аерологічні, метеорологічні, кліматичні, тропосферні, стратосферні, верхньоатмосферно-космічні (джерела ризиків - об’єкти - космічні апарати у термосфері, екзосфері Землі, а також у ближньому космосі). До підгрупи верхньоатомосферно-космічних ризиків ІКТ ми включили такі класи, як: ракетні, корабельні, супутникові, орбітальні. При цьому варто наголосити, що об'єктами формування IКТризиків в даних класах виступають ракети-носії, пілотовані одноразові космічні кораблі, суборбітальні геофізичні ракети (безпілотні ракети дослідницького призначення для вивчення стану атмосфери, що літають вище лінії Кармана, тобто висоти 100 км над земною поверхнею), метеорологічні ракети (безпілотні дослідницькі ракети, які літають до 100 км у нижній термосфері), безпілотні штучні супутники Землі, орбітальні станції (пілотовані штучні супутники Землі), багаторазові космічні кораблі “шатли”. В кожному з цих класів виділяються такі конкретні підкласи екоризиків від IКТ-технологій у верхніх шарах атмосфери та у ближньому космосі: ризики механічного забруднення територій i ураження людей обломками відпрацьованих космічних 
апаратів; ризики хімічного зараження територій залишками космічного обладнання; загрози зіткнень космічних апаратів у ближньому космосі; ризики забруднення навколоземного космічного простору так званим "космічним сміттям"; терморизики, що несуть загрозу фізичному стану космічних апаратів і життю астронавтів; ризики радіаційного ураження техніки і людини; екзозагрози, що пов'язані 3 фізичними властивостями зовнішньої оболонки земної атмосфери. Як правило, загрози від падіння обломків від апаратів, запущених у космос, на людей, дуже низькі, поте один випадок було зафіксовано у січні 1997 року в США через падіння ракети-носія “Дельта-2", запущеного 3 космічного центру Кеннеді у штаті Флорида. Для унеможливлення попадання обломків в людей, фахівці ретельно розраховують траєкторію сходження відпрацьованих супутників з орбіти в атмосферу 3 таким загальноприйнятим розрахунком, щоб ймовірність попадання в людей незгорілих в атмосфері фрагментів космічного обладнання була меншою за $0,01 \%$. В той же час, кількість об'єктів космічного сміття, що знаходяться на сьогодні на орбіті нашої планети, сягає бл. 500 тис. об'єктів; їх габарити варіюють від дуже малих до розмірів з автобус, таких як європейський супутник "Envisat", що виявився непридатним до використання. Враховуючи це, потрібно зазначити, що жоден 3 вищеназваних обломків не може постійно знаходитися на навколоземній орбіті і рано чи пізно обов'язково впаде на землю; кількість таких об'єктів космічного сміття 3 кожним роком збільшується, незважаючи на те, що супутники стають все більш компактнішими. Наприклад, лише одна компанія "SpaceX" планує найближчими роками створити свою власну Інтернет-мережу, для чого необхідно 4425 нових супутників [9]. Цей стан справ призводить до механічного забруднення окремих ділянок земної поверхні обломками космічного сміття, утилізацією якого ніхто не займається, дбаючи лише про те, щоб обломки падали на незаселені території. Переважно мова йде про т.зв. кладовище космічних кораблів, локалізоване в південній частині Тихого океану, на схід від Нової Зеландії і на південь від о. Різдва. Воно сягає глибини 4000 метрів i закрите для судноплавства, а щорічно в середньому відбувається по декілька десятків затоплень космічних відходів. Одні з найбільш масштабних затоплень останніх десятиліть - це затоплення над даним районом орбітальної радянськоросійської станції "Мир” у 2001 р., російського вантажного корабля "Прогрес М-56" у 2006 р., російського вантажного корабля "Прогрес М28М" у 2015 р., європейського автоматичного вантажного корабля серії ATV “Жуль Верн” в 2008 р., вантажного корабля "Dragon" компанії "SpaceX" у 2018 р. Росія [5], наприклад, утилізувала тут в загальній сукупності 140 своїх вантажних кораблів різних типів. Необхідно зауважити, що були i незаплановані райони падіння обломків відпрацьованих космічних кораблів - це західна частина Австралії, що сталося у 1979 р. при падінні залишків американської орбітальної станції "Skylab", a також Аргентина, що відбулося у 1991 р. при утилізації залишків радянської орбітальної станції “Салют-7" і північно-західний район від о. Таїті, коли у 2018 р. 3 орбіти в нижні шари атмосфери зійшла утилізована китайська космічна станція “Тяньгун-1".

Захаращення навколоземної орбіти космічним сміттям становить одну 3 найбільш серйозних проблем сьогодення. Станом на 2014 рік [8], найбільше космічного сміття продукували такі країни, як: РФ - 39,7\%, США - 28,9\%, КНР $22,8 \%$, інші країни $-8,6 \%$. Найгірший сценарій розвитку подій в найближчому майбутньому описується так званим ефектом Кесслера, згідно 3 яким надмірне накопичення космічного сміття на орбіті Землі призведе до повної непридатності ближнього космосу для використання i колонізації людиною, передусім через “принцип доміно" зіткнення діючих космічних апаратів 3 об'єктами космічного сміття неодмінно виводить їх з ладу, в результаті чого кількість космічного сміття лише зростає.

Проблеми, пов'язані з зіткненням космічних кораблів між собою та 3 елементами космічного сміття також надзвичайно актуальні. За всю еру космонавтики у ближній космос було запущено понад 6 тисяч різних супутників - науководослідницьких, біосупутників, розвідницьких, телекомунікаційних, метеорологічних супутників, нині в робочому стані на орбіті знаходиться близько 8003 них. Чимало 3 них, зіштовхуючись, перетворюються в космічне сміття, в результаті чого несуться порівняно великі економічні та екологічні збитки. Найбільш гучний такий інцидент трапився у лютому 2009 року, при зіткненні американського штучного супутника "Iridium 33" з російським супутником "Космос-2251" над євразійським півостровом Таймир. Були й менш масштабні зіткнення: у 1994 році сталося зіткнення космічного корабля "Союз ТМ-17” з орбітальною космічною стацією "Мир”, у 1997 році подібне відбулось, коли "Прогрес М34" врізався у космічну станцію "Мир". Космічне сміття також являє собою серйозну загрозу, якщо 3 ним стикнуться стаціонарні космічні апарати. Як говорилось вище, 3500 тисяч фрагментів космічного сміття 200 тисяч (40\%) рукотворні і 
розміром більше яблука, а швидкість їх обертання навколо нашої планети більше 28 тисяч кілометрів на годину. Зрозуміло, що будь-яке зіткнення 3 ними призведе до серйозних ушкоджень космічних кораблів i штучних супутників. Прикладом може слугувати випадок, що стався у 2013 році при зіткненні російського ретрорефлекторного супутника "BLITS" 3 великим обломком китайського космічного сміття, що дрейфувало ще з 2007 року. В тому ж 2013 р. еквадорський супутник “Пегас" зіткнувся 3 хмарою обломків російського космічного сміття від ракети-носія “Циклон-3".

Значну загрозу становлять i продукти хімічного розкладу від відпрацьованих на орбіті космічних об'єктів, тобто це передусім компоненти твердого і рідкого ракетного палива. У першу чергу, мова йде про токсичну речовину гідразин, яка перебуває у складі ракетного палива. Критично допустимий рівень цієї речовини в повітрі $0,1 \mathrm{mг} / \mathrm{M}^{3}$. У великих концентраціях вона викликає гостре хімічне отруєння і призводить до летального випадку. Ця речовина не завжди згоряє в нижніх шарах атмосфери разом 3 відпрацьованими космічними апаратами, а тому потрапляе на ділянки земної поверхні. Екотоксичними, безумовно, $€$ також несиметричний диметилгідразин, який $\epsilon$ канцерогеном й компонентом ракетного палива i аерозин - суміш несиметричного диметилгідразину і гідразину. Те ж саме можна сказати і про інші складники ракетного палива нафтопродукти, нітрометан, рідкий водень, озон, гібриди бору, нітрогліцерин, які несуть велику загрозу для життя і здоров'я людини. Порівняно незначну загрозу несуть такі речовини, як карамельне тверде ракетне паливо, яке здатне викликати в людини у формі продукту свого горіння карбонату калію хімічні опіки. Інші речовини більш небезпечні саме для екосистем. Трифторид азоту, наприклад, $\epsilon$ парниковим газом i негативно впливає на екологію, оскільки провокує глобальне потепління. Перхлорати згубно діють на рослинний покрив землі. Існують ризики витоку цих небезпечних речовин, проникнення їх решток з верхніх шарів атмосфери при сходженні з орбіти космічного сміття, забруднення атмосферного повітря, при цьому ІКТ тут присутні у двох функціональних типах: як моніторингові системи або як системи управління космічних польотів $\mathrm{i}$ сходження 3 орбіти рукотворних космічних об'єктів.

Дають про себе знати й терморизики, високотемпературні загрози для космічної техніки й астронавтів, які мають місце у вищих шарах атмосфери. Повітря в термосфері розріджене, а його температура коливається від $200 \mathrm{~K}\left(-73^{\circ} \mathrm{C}\right)$ до $2000 \mathrm{~K}\left(1727^{\circ} \mathrm{C}\right)$ в залежності від рівня сонячної активності і висоти. 3 іншого боку, така висока температура повітря в термосфері не унеможливлює космічні польоти, оскільки висока розрідженість повітря не дає змогу нагріти обшивку космічних кораблів до високих температур, тому що кількість молекул дуже мала і частота їх зіткнень з судном дуже незначна. Для людини висока температура навколишнього середовища (вище температури тіла) призводить до серйозних функціональних порушень системи терморегуляції організму. При температурі $+30^{\circ} \mathrm{C}$ теплообмін зупиняться, а тепловий баланс підтримується за рахунок інтенсивного потовиділення, що може призвести до дегідратації - обезводнення організму людини, а після температури вище $+60^{\circ} \mathrm{C}$ починається процес інтенсивного накопичення тепла в організмі.

Окремим різновидом терморизиків $є$ джоулева теплота, яка появляється через дію електричних струмів магнітосфери. Вона тягне за собою значне розігрівання верхніх шарів атмосфери в приполярних районах $\mathrm{i}$ зазвичай це явище проявляє себе при магнітних бурях. ІЇ̈ особливість в тому, що таке розігрівання відбувається нерівномірно, а отже, існують значні ризики потрапляння в такі зони в термосфері космічних апаратів з екіпажами.

Як відомо, всі пілотовані космічні місії відбуваються на висотах 200-500 км, а вище 500 км протягаються радіаційні пояси, небезпечні для людини, яка $€$ членом екіпажу космічного судна; нижче 200 км польоти не проводять через сильне тертя з повітрям. У зв'язку з цим варто виділити ще один важливий підклас загроз - ризиків радіаційного випромінювання. Поміж тим, не всюди по планеті радіоактивне випромінювання починається на висоті 500 км, як, наприклад, над Атлантикою, над Індонезією він стартує з висоти 1300 км. Можна сказати, що це $\epsilon$ постійні ризики радіоактивного випромінювання. Проте не треба забувати i про можливі втрати від квазістаціонарних радіаційних поясів, які формуються в результаті спалахів на Сонці або викидом у верхні шари атмосфери радіоактивних продуктів після випробувань ядерної зброї. Сонячна радіація також $\epsilon$ серйозним джерелом ризику, вона буває пряма і розсіяна: середня величина прямої радіації на території України

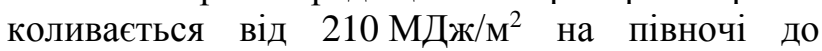
290 МДж/м² на півдні; середня величина розсіяної радіації (частина сонячної радіації, розсіяна в атмосфері) по території України сягає 200215 МДж/м². Крім згубного ультрафіолетового впливу, сонячна радіація являється потужним 
канцерогеном. Спалахи на Сонці призводять до геомагнітних бур, а отже, дуже часто виводять 3 ладу ІКТ-техніку. Ці викиди хмар плазми здатні порушувати зв'язок, навігаційні космічні системи, енергосистеми, ЛЕП, провокувати вихрові індукційні струми в трубопроводах i трансформаторних системах, в залізничному господарстві. Крім того, моніторинг за сонячними спалахами проводиться 31975 року через спеціальну мережу супутників "GOES". Найсильніший спалах був зафіксований у 2003 році 3 потужність Х28, сильні спалахи спостерігалися у 1989 році з потужністю Х20, у 1978 р. $з$ потужністю X15, у 2017 р. $з$ потужністю $\mathrm{X} 9,3$. Сильне сонячне випромінювання здатне змінювати фізичні властивості верхньої атмосфери, в результаті чого густина повітря в ній швидко зростає, що призводить до зменшення висоти польотів космічних апаратів, як пілотованих, так і штучних супутників. Механізм періодичності протікання геомагнітних бур наступний. Цикл сонячної активності сягає 11 років. За цей проміжок часу відбувається 600 геомагнітних бур, які змінюють іоносферу Землі, а відповідно умови поширення хвиль, що, звісно, не може негативно не впливати на комунікаційну (супутниковий зв'язок i телебачення) й комп'ютерну техніку. Досить часто надмірну сонячну активність називають причиною невдалих запусків ракет-носіїв на орбіту через іï вплив на бортове комп'ютерне обладнання. Так, наприклад, було із запуском у 2011 році російської автоматичної міжпланетної станції “Фобос-Грунт", а також ракети “Союз-2.1б” у 2017 р. Підсумовуючи, можна сказати, що негативний вплив магнітних бур для сфери застосування IКТ зводиться до двох негативних аспектів: 1) накопичення рівня радіації призводить до виведення апаратів 3 ладу; 2) виникнення паразитуючих індукційних струмів в результаті варіації геомагнітного поля; 3) формування всіляких перешкод в радіодіапазоні.

Окремо варто виділити черговий підклас загроз - екзоризики, наявність котрих зв'язана 3 особливостями верхнього шару атмосфери Землі. По-перше, це загрози, пов'язані зі значними втратами енергії для космічних апаратів та штучних супутників, запущених вище 500-1000 км, тобто туди, де починається земна екзосфера. По-друге, всі об'єкти в ній (в дуже розрідженому повітряному середовищі) можуть рухатися лише по балістичним траєкторіям, а якщо у них друга космічна швидкість, то існує високий ризик вилетіти 3 навколоземної орбіти у відкритий космос, а, отже, і виникає можливість втрати космічних апаратів. По-третє, недостатній моніторинг сонячної активності може призвести до непередбачуваних негативних наслідків, пов'язаних 3 недостатнім знанням оперативних меж екзосфери, бо висока сонячна активність сприяє росту товщини екзосфери, а тому i розширення іï поточних границь. По-четверте, вище 2000 км земне тяжіння не впливає на супутники, а тому існує реальна загроза довготривалого (на тисячолітню перспективу) накопичення шару космічного сміття на цій висоті. Екзосфера - середовище для польотів безпілотних штучних супутників. Так, на висоті 20 тис. км зосереджені супутники "GPS" та "ГЛОНАСС", відпрацьовані об'єкти яких залишаться довговічним космічним сміттям. Поп'яте, незважаючи на те, що екзосфера Землі простягається на висоту до 100000 км, для освоєння людиною вона майже не придатна; максимальний рівень висоти, досягнутий людиною, був зафіксований у вересні 1966 року під час місії американського пілотованого космічного корабля “Джеміні-11”, запущеного за допомогою ракети-носія "Titan II GLV", коли було встановлено рекорд висоти у 1372 км.

До групи астрофізичних ризиків IКТ ми відносимо всі потенційні загрози, пов'язані із застосуванням комп'ютеризованої техніки за межами планети Земля i iï атмосфери. Ця комп'ютеризована техніка отримала конкретне конструкційне втілення - у вигляді автоматичних міжпланетних станцій та пілотованих космічних кораблів. Усю множину астрофізичних ІКТзагроз можна ділити на: іншопланетні та міжпланетні. Перші пов'язані із ризиками функціонування космічної апаратури на поверхні інших планет (Місяця, Венери, Марсу, Титану (супутника Сатурна), Меркурія). Це були відомі американські, радянські та російські космічні програми "Вікінг”, “Луна”, "Піонер”, “Венера", “Вояджер”, "Вега", "Марінер”, "Нові горизонти”, "Екзомарс" тощо. Міжпланетні ризики застосування комп'ютерної космічної техніки проявляють себе на апаратах в міжпланетному просторі, а також на поверхнях непланетних небесних тіл (астероїдів, комет): астероїди Ерос, Ітокава, комета Чурюмова-Герасименко. I в складі першої, i у складі другої підгруп виділяються: радіотехнічні, астроінерціальнонавігаційні, фототелевізійні, науководослідницькі, тепло-енергетичні, біологічні ризики IКТ-систем на автоматичних міжпланетних станціях та пілотованих космічних кораблях міжпланетного призначення. В першу чергу маються на увазі різноманітні можливі неполадки апаратури, втрата зв'язку 3 центром управління польотами, надходження недостовірної інформації 3 апарату на Землю, 
неправильно

космічному

обладнання,

проведені

екс

просторі, втрата

проблема утилізації зношеного космічного міжпланетного апарату, перегрів обладнання, можливі поломки у роботі термоелектричних радіоізотопних генераторів, сонячних батарей, що призводять до припинення енергоживлення пристрою, аварії ракет-носіїв, зараження земними мікроорганізмами поверхні інших планет, занесеними автоматично 3 космічним апаратом. Наприклад, останній існував у 2017 році, коли американський апарат "Кассіні" після вичерпання потужностей був направлений в атмосферу Сатурна. Втрати зв'язку між апаратом та центром управління 3 Землі досить часта неполадка, яка коштує серйозних економічних та екологічних збитків у процесі реалізації космічних програм. Перший радянський місяцехід “Луноход-1" у 1971 р. закінчив свою роботу саме по цій причині. Ще одна традиційно серйозна загроза - невдалі запуски ракет-носіїв цих апаратів. Наприклад, у серпні 1969 р. це була ракета програми "ПіонерE”, яка упала під час запуску в Атлантичний океан. Відомим випадком перегріву обладнання i його виходу 3 ладу стало завершення місії радянського місяцеходу “Луноход-2” у 1973 р. Тепло-енергетичні екологічні ризики особливо небезпечні, так як при аварії радіоізотопних генераторів енергії роботи обладнання вони несуть гамма-випромінювання, виділяють радіоактивні аерозолі (зокрема, в першу чергу ізотопи радону - прозорого інертного газу, а також торону, актинону), ртутні пари, часточки урану-232, ізотопи трансуранових елементів типу плутонію-238, каліфорнію-248, полонію-208, ейнштейнію-254, фермію-257, кюрію-245 тощо. Так, у 1964 р. при аварії американського супутника навігації “Транзит-5B” майже кілограм плутонію 238 з установки "SNAP-9A" розсіявся у атмосфері Землі, спричинивши суттєвий ріст рівня радіоактивного фону в даній місцевості. Подібний інцидент стався і в 1970 р. при поверненні пілотованої місії з Місяця “Аполлон13", а також у 1996 році при виході 3 орбіти російської автоматичної станції “Марс-96”. При запуску першого радянського прототипу місяцеходу “Луноход-0" у лютому 1969 р. відбувся інцидент 3 ризиком забруднення території від радіоізотопного джерела енергії на основі полоніду іттрію, проте завдяки збереженню герметичності захисної капсули зараження місцевості на сталося.

Висновки i перспективи подальших досліджень. Таким чином, впровадження цифрових космічних технологій у верхніх шарах земної атмосфери та міжпланетному просторі несуть собою значні екологічні ризики та пов'язані 3 ними економічні втрати. 3 одного боку, це цілий спектр загроз можливого екологічного забруднення: механічного, хімічного, теплового, біологічного; 3 іншої сторони - загрози як астронавтам, які мають справу 3 високоточним обладнанням, так i населенню територій - зон можливого ураження безпосередньо на земній поверхні. Унеможливлення серйозних екологічних наслідків та мінімізація негативного впливу вищевказаних загроз вимагають впровадження систем екологічного менеджменту для роботи 3 верхніми шарами атмосфери.

\section{ПЕРЕЛІК ВИКОРИСТАНИХ ДЖЕРЕЛ}

1. Бацманова Л.С. Розміщення продуктивних сил України: Навч.-метод. посіб. / Л.С. Бацманова. - Луганськ: Альма-матер, 2006. - 134 с.

2. Воздушная оболочка Земли: статті [Електронний ресурс] // Знай мир, в котором ты живёшь. - Режим доступу: http://znaj.net/article/view/AIR.html.

3. Калесник С.В. Общие географические закономерности Земли / С.В. Калесник. - М.: Мысль, 1970. - 283 с.

4. Назарук М.М. Екологічний менеджмент. Запитання та відповіді : навч. посібник / М.М. Назарук, І.Б. Койнова. - Львів : Еней, 2004. - 216 с.

5. Офіційний сайт Державної корпорації по космічній діяльності “Роскосмос” [Електронний ресурс]. - Режим доступу: https://www.roscosmos.ru

6. Позденеева Н. Современный взгляд на глобальные экологические изменения / Н. Позденеева // Краєзнавство. Географія. Туризм. - 2002. - №25-28. - С. 8-10.

7. Сухарев С.М. Основи екології та охорони довкілля / С.М. Сухарев, С.Ю. Чундаков, О.Ю. Сухарева. - К.: Центр навчальної літератури, 2006. - 394 с.

8. Черный И. Космический мусор и его коллеги [Электронный ресурс] / И. Черный // Новости космонавтики. - 2014. - №10. - Режим доступа: http://novosti-kosmonavtiki.ru/

9. FCC approves SpaceX plan for 4,425-satellite broadband network [Електронний pecypc] // Techcrunch. - 2018. - Mar 30. - Режим доступу: https://techcrunch.com/2018/03/29/fcc-approves-spacex-plan-for-4425-satellite-broad band-network/ 


\section{REFERENCES}

1. Batsmanova, L. S. (2006). Rozmishchennya produktyvnykh syl Ukrayiny [Placement of productive forces of Ukraine] (Teaching methodical manual). Luhansk: Alma Mater. [in Ukrainian].

2. Vozdushnaya obolochka Zemli [Earth's air shell]. Website Znay mir, v kotorom ty zhivosh' [Know the world in which you live]. Retrieved from http://znaj.net/article/view/AIR.html [in Russian].

3. Kalesnik, S. V. (1970). Obshchiye geograficheskiye zakonomernosti Zemli [General geographic patterns of the Earth]. Moscow: Thought. [in Russian].

4. Nazaruk, M. M., \& Koynova, I. B. (2004). Ekolohichnyy menedzhment. Zapytannya ta vidpovidi [Ecological management. Questions and Answers] (Teaching Manual). Lviv: Anei. [in Ukrainian].

5. Official site of the State Corporation for Space Activities "Roskosmos". (2018). Retrieved from https://www.roscosmos.ru [in Russian].

6. Pozdeneyeva, N. (2002). Sovremennyy vzglyad na global'nyye ekologicheskiye izmeneniya [Modern view on global environmental changes]. In Krayeznavstvo. Heohrafiya. Turyzm [Regional studies. Geography. Tourism]: Vol. 2528 (pp. 8-10). [in Russian].

7. Sukharev, S. M., Chundakov, S. Yu., \& Sukhareva, O. Yu. (2006). Osnovy ekolohiyi ta okhorony dovkillya [Fundamentals of ecology and environment protection]. Kyiv: Center for Educational Literature. [in Ukrainian].

8. Chernyy, I. (2014). Kosmicheskiy musor i yego kollegi [Space debris and his colleagues]. Novosti kosmonavtiki News of Cosmonautics, 10. Retrieved from http://novosti-kosmonavtiki.ru/ [in Russian].

9. FCC approves SpaceX plan for 4,425-satellite broadband network (2018, Mar 30). Website Techcrunch. Retrieved from https://techcrunch.com/2018/03/29/fcc-approves-spacex-plan-for-4425-satellite-broad band-network/

Одержано 11.09.2018 p. 